\title{
Teknologi Pendidikan: Kajian Aplikasi Ruangguru Berdasarkan Prinsip dan Paradigma Interaksi Manusia dan Komputer
}

\author{
Dian Rahadian ${ }^{1}$, Gina Rahayu², Risma Rahma Oktavia ${ }^{3}$ \\ Pendidikan Teknologi Informasi, Institut Pendidikan Indonesia Garut \\ 1dianrahadian@institutpendidikan.ac.id \\ ${ }^{2}$ ginaa.rahayu@gmail.com \\ ${ }^{3}$ oktaviarisma9@gmail.com
}

\begin{abstract}
This Ruangguru application study aims to determine the relevance of application functions based on the principles and paradigms of Human and Computer Interaction (HCI). In this study, the aspects evaluated included aspects of human, technology, usability, and ergonomics. The interest in studying the Ruangguru application is based on several sources stating that Ruangguru is believed to be "Best Education Platform". So from that, it was examined several aspects to determine the extent of the relationship between the Ruangguru application and the HCI principle. After the study was conducted, the Ruangguru application was assessed to have fulfilled these aspects. So it's no wonder the Ruangguru application is used as an online learning center among Indonesian students.
\end{abstract}

Keywords- HCI, Ruangguru, Human, Technology, Usability, and Ergonomic.

\begin{abstract}
Abstrak - Kajian aplikasi Ruangguru ini bertujuan untuk mengetahui keterkaitan fungsi aplikasi berdasarkan prinsip dan paradigma Interaksi Manusia dan Komputer (IMK). Dalam kajian ini aspek yang dievaluasi diantaranya aspek human, technology, usability, dan ergonomic. Ketertarikan kajian aplikasi Ruangguru ini berdasarkan beberapa sumber yang menyatakan bahwa ruangguru dipercaya sebagai "Best Education Platform". Maka dari itu dikaji beberapa aspek untuk mengetahui sejauh mana keterkaitan aplikasi Ruangguru dengan prinsip IMK. Setelah dilakukan kajian, aplikasi Ruangguru dinilai telah memenuhi aspek-aspek tersebut. Jadi tidak heran aplikasi Ruangguru digunakan sebagai pusat belajar online di kalangan pelajar Indonesia.
\end{abstract}

Kata Kunci- IMK, Ruangguru, Manusia, Teknologi, Kegunaan, dan Ergonomi.

\section{PENDAHULUAN}

Memasuki era globalisasi yang identik dengan istilah modernisasi, semua aspek kehidupan menunjukkan perubahan. Perubahan mengikuti perkembangan teknologi yang tergolong begitu pesat. Dewasa ini, teknologi merupakan salah satu penawaran yang sangat menggiurkan bagi setiap orang. Globalisasi adalah suatu proses pembaharuan yang mencakup semua aspek kehidupan, menggunakan teknologi sebagai media utama. Teknologi sebagai media utama, memegang peranan penting dalam setiap perkembangan tak terkecuali pada bidang pendidikan. Penyelenggaraan pendidikan dimaksudkan untuk membantu manusia menjadikan dirinya sebagaimana mestinya sesuai dengan yang mereka mampu, dan para pendidik harus mampu memahami mereka dalam aktualitas, kemungkinan-kemungkinan dan idealitasnya serta para pendidik harus tahu bagaimana menumbuhkan perubahanperubahan yang diinginkan oleh mereka (Rahadian, 1:2016). Pendidikan mempunyai peranan penting dalam kemajuan bangsa dan negara, baik negara maju maupun negara yang berkembang. Perkembangan dan kemajuan suatu negara dapat dilihat dari bagaimana 
pendidikan mampu membentuk Sumber Daya Manusia (SDM) yang berkualitas.

Ketika ilmu pengetahuan dan teknologi berkembang sangat pesat, proses pembelajaran tidak lagi di monopoli oleh kehadiran guru di dalam kelas. Siswa dapat belajar di mana saja dan kapan saja. Siswa bisa belajar apa saja sesuai dengan minat dan gaya belajar masing-masing siswa yang berbeda. Seorang desainer pembelajaran dituntut untuk dapat merancang pembelajaran dengan memanfaatkan berbagai jenis media dan sumber belajar yang sesuai agar proses pembelajaran berlangsung secara menyenangkan, efektif, dan efisien. Rossi dan Biddle (1966: 3) mengemukakan bahwa media pembelajaran adalah seluruh alat dan bahan yang dapat dipakai untuk tujuan pendidikan, seperti radio, televisi, buku, koran, majalah, dan sebagainya. Secara lebih khusus, pengertian media dalam proses belajar mengajar cenderung diartikan sebagai alat-alat grafis, photografis, atau elektronis untuk menangkap, memproses, dan menyusun kembali informasi visual atau verbal.

Di era globalisasi seperti sekarang ini, pelajar lebih akrab dengan teknologi khususnya smartphone dan di sisi lain, dibutuhkan sikap adil baik dari guru maupun masyarakat secara umum, yang menunjukkan identitas dan karakter guru sebagai profesional dan anggota masyarakat yang edukatif (Rahadian, 1:2015). Proses pembelajaran pun tak asing lagi dilakukan dengan bantuan smartphone tersebut, baik menggunakan mesin pencari (Google Chrome, Mozilla, Opera, maupun web browser lain) bahkan melalui bantuan aplikasi belajar berbasis android yang dapat dengan mudah di dapat melalui play store dan app store. Dengan teknologi tersebut, sering kali pelajar lebih senang bahkan lebih paham belajar menggunakan bantuan aplikasi belajar online dari pada belajar konvesional di kelas. Teknologi informasi memberikan media baru untuk menyebarkan informasi, yaitu media digital. Banyak institusi pendidikan di Indonesia sudah menggunakan media digital untuk menunjang pembelajaran, seperti penggunaan platform belajar digital Ruangguru. Penggunaan aplikasi ruangguru tidak akan terlepas dari interaksi manusia dengan komputer. Aplikasi ruangguru ini sering digunakan oleh banyak rata-rata pelajar khususnya di Indonesia. Ruangguru dianggap merupakan fasilitas belajar lengkap dan mudah karena selain dapat digunakan sebagai fasilitas belajar digital online, pembelajaran juga dapat dilakukan dimana saja dan kapan saja.

Berdasarkan latar belakang tersebut penulis ingin melakukan kajian terhadap aplikasi Ruangguru berdasarkan paradigma Interaksi Manusia dengan Komputer (IMK).

1.1. Rumusan Masalah

Berdasarkan latar belakang diatas, maka rumusan masalah dalam kajian ini sebagai berikut.

1) Bagaimana aspek human pada aplikasi ruangguru?

2) Bagaimana aspek technology pada aplikasi ruangguru?

3) Bagaimana aspek usability pada aplikasi ruangguru?

4) Bagaimana aspek ergonomic pada aplikasi ruangguru?

1.2. Tujuan

Tujuan kajian ini berdasarkan rumusan masalah adalah sebagai berikut.

1) Untuk mengetahui aspek human pada aplikasi ruangguru

2) Untuk mengetahui aspek technology pada aplikasi ruangguru

3) Untuk mengetahui aspek usability pada aplikasi ruangguru

4) Untuk mengetahui aspek ergonomic pada aplikasi ruangguru

\section{KAJIAN PUSTAKA}

2.1 Interaksi Manusia dan Komputer

2.1.1 Pengertian Interaksi Manusia dan Komputer

Interaksi merupakan komunikasi antara dua atau lebih objek yang saling mempengaruhi satu sama lain. Interaksi ini tidak akan berjalan dengan baik, apabila salah satu objek yang berinteraksi mengalami hambatan. Interaksi manusia dan komputer merupakan komunikasi dua arah antara pengguna (user) dengan sistem komputer yang saling mendukung untuk mencapai suatu tujuan tertentu. ACM SIGCHI [1992] mendefinisikan interaksi manusia dan komputer merupakan disiplin ilmu yang mempelajari desain, evaluasi, implementasi dari sistem komputer interaktif untuk dipakai oleh manusia beserta studi tentang faktor-faktor utama dalam lingkungan interaksinya.

(Insap Santoso, 2004) Pengertian Interaksi manusia dan komputer adalah disiplin ilmu yang berhubungan dengan perancangan, evaluasi, dan implementasi sistem komputer interaktif untuk digunakan oleh manusia, serta 
studi fenomena-fenomena besar yang berhubungan dengannya. Human Computer Interaction yaitu studi yang mempelajari hubungan interaksi antara manusia, komputer dan penugasan. Prinsipnya bagaimana manusia dan komputer dapat secara interaktif menyelesaikan penugasan dan bagaimana sistem yang interaktif tersebut dapat dibuat. Adapun pemahanlain terhadap HCI dimana ketika membangun sebuah sistem informasi, seorang desainer atau pengembang sistem harus " memperhatikan faktor interaksi manusia dan komputer karena sistem informasi yang dibuat oleh manusia dan tujuannya untuk manusia" (Prihati).

Dari penjelasan diatas, interaksi manusia dan komputer tidak hanya pada tampilan interfacenya saja, tetapi juga memperhatikan aspek-aspek pamakai, implementasi sistem rancangannya dan fenomena lingkungannya. Misalnya, sistem tersebut mudah dioperasikan, dipelajari, dan lain-lain.

Komputer dan peralatan lainnya harus dirancang dengan pemahaman bahwa penggunanya memiliki tujuan atau tugas khusus dan ingin menggunakannya sesuai dengan karakteristik tugas yang akan diselesaikannya tersebut. Agar dapat terpenuhi, perancang sistem perlu mengetahui bagaimana berfikir dalam lingkup tugas user yang sesungguhnya dan menerjemahkannya ke dalam sistem.

\subsubsection{Ruang Lingkup Interaksi Manusia dan} Komputer (IMK)

Interaksi manusia dan komputer memiliki 3 komponen yaitu manusia, komputer dan interaksi. Ketiga komponen tersebut saling mendukung dan berkaitan satu sama lain. Manusia merupakan pengguna (user) yang memakai komputer. User ini berbeda-beda dan memiliki karakteristik masing-masing sesuai dengan kebutuhan dan kemampuannya dalam menggunakan komputer. Komputer merupakan peralatan elektronik yang meliputi hardware (perangkat keras) dan software (perangkat lunak). Seperti yang kita ketahui bahwa prinsip kerja komputer terdiri dari input, proses dan output. Komputer ini akan bekerja sesuai dengan instruksi yang diberikan oleh pengguna. User memberi perintah pada komputer dan komputer mencetak/menuliskan tanggapan pada layar tampilan.

\subsection{Aspek Human}

Manusia sebagai pengolah informasi menerima masukan, menyimpan, memanipulasi dan menggunakan informasi, dan bereaksi terhadap informasi yang diterima. Informasi diterima melalui indera, khususnya, dalam kasus penggunaan komputer, melalui penglihatan, pendengaran dan sentuhan. Itu disimpan dalam memori, baik untuk sementara di indera atau memori yang berfungsi, atau secara permanen dalam memori jangka panjang. Ini kemudian dapat digunakan dalam penalaran dan pemecahan masalah. Situasi familiar yang sering terjadi memungkinkan orang memperoleh keterampilan dalam domain tertentu, karena struktur informasinya menjadi lebih jelas. Namun, ini juga dapat menyebabkan kesalahan, jika konteksnya berubah. Persepsi dan kognisi manusia adalah kompleks dan canggih tetapi mereka bukan tanpa keterbatasan mereka. Disini harus dipertimbangkan beberapa keterbatasan. Pemahaman tentang kemampuan dan keterbatasan manusia sebagai pengolah informasi dapat membantu kita untuk merancang sistem interaktif yang mendukung yang pertama dan mengkompensasi yang terakhir. Prinsip, pedoman, dan model yang dapat berasal dari psikologi kognitif dan teknik yang diberikannya merupakan alat yang tak ternilai bagi perancang sistem interaktif.

Manusia dianggap sangat kompleks, tidak konsisten, kurang deterministik (sulit diprediksi). Maka dari itu seorang developer harus memahami kemampuan dan keterbatasan manusia, memahami bagaimana membuat sistem yg dapat diandalkan dan aman untuk digunakan manusia dapat dicapai dengan mempelajari tentang aspek-aspek psikologi kognitif manusia, bagaimana manusia merasakan dunia disekitarnya, bagaimana manusia menyimpan \& memproses informasi serta memecahkan masalah, bagaimana manusia memanipulasi objek secara fisik. Manusia adalah aspek pertama dan utama karena manusia adalah subjek di dalam sistem komputer. Sistem komputer membantu manusia dalam menyelesaikan masalah-masalah dengan cara yang lebih efektif dan efisien. Studi manusia dalam IMK diharapkan akan menghasilkan suatu sistem yang dapat diandalkan, aman, dan nyaman bagi manusia.

Keterbatasan manusia dalam memproses informasi yang mendorong terciptanya sistem komputer. Informasi yang diterima dan respon yang diberikan oleh manusia terbatas melalui saluran yang dimiliki oleh manusia. Saluran masukan yang dimiliki oleh manusia terdiri dari penglihatan (visual), 
pendengaran (auditory), sentuhan (haptic) dan gerakan (movement), dan informasi yang tersimpan di dalam memori manusia. Informasi yang tersimpan diproses dan diolah menjadi bahan pertimbangan, pemecahan masalah, dan keterampilan manusia.

\subsection{Aspek Teknologi}

Dalam aspek teknologi, konsep interaksi manusia dan komputer mencakup beberapa bagian diantaranya sebagai berikut :

a) Memory

Secara umum ada 3 jenis /fungsi memori :

- tempat penyaringan (sensor)

- tempat memproses ingatan (ShortTerm-Memory)

- memori jangka panjang (Long-TermMemory)

b) Register Sensori

Terdiri dari 3 saluran penyaring :

- Iconic : menerima rangsang penglihatan

- Echoic : menerima rangsang suara

- Haptic : menerima rangsang sentuhan c) Storage : Secara umum penyimpanan dalam IMK terbagi ke dalam 2 jenis yaitu penyimpanan internal (otak manusia) dan penyimpanan eksternal (memori komputer) d) Input : perangkat input meliputi text input device baik itu perangkat masukan maupun pointer yang digunakan dalam merancang sebuah system.

e) Output : proses keluaran dalam IMK mencakup proses display yang dilakukan oleh sebuah system/aplikasi dalam menjalankan program.

\section{$2.4 \quad$ Aspek Ergonomi}

Ergonomi adalah suatu ilmu tentang manusia dalam usaha untuk meningkatkan kenyamanan di lingkungan kerjanya. Istilah ergonomi berasal dari bahasa latin yaitu Ergon (kerja) dan Nomas (hokum alam). Istilah ini dapat didefinisikan sebagai studi tentang aspekaspek manusia dalam lingkungan kerjanya yang ditinjau secara anatomi, fisiologi, psikologi, engineering, manajemen dan perancangan/desain (Nurmianto, 1996).

Maksud dan tujuan dari disiplin ergonomi adalah mendapatkan suatu pengetahuan yang utuh tentang permasalahanpermasalahan interaksi manusia dengan teknologidan produk-produknya, sehingga dimungkinkan adanya suatu rancangan sistem manusia-mesin (teknologi) yang optimal. Dengan demikian disiplin ergonomi melihat permasalahan sebagai suatu sistem dengan pemecahan melalui proses pendekatan system (Wignjcsocbroto., 1995).

Ergonomi menjadi ilmu yang menghadirkan eksplorasi sistem bidang manusia-mesin-lingkungan, humanfactors, dan ergonomi dalam menghasilkan kenyamanan, keamanan, produktivitas, dan sistem yang mudah digunakan oleh pengguna (Wickens., 1998).

Ergonomi juga didefinisikan sebagai pengetahuan yang memperhatikan perancangan obyek untuk manusia (peralatan) sehingga seseorang mampu menimbulkan "functional effectiveness" dan kenikmatan-kenikmatan pemakaian dari peralatan, fasilitas maupun lingkungan kerja yang dirancang. Salah satu analisis dan penelitian ergonomi meliputi psikologi yang fisiologis mengenai berfungsinya otak dan sistem syaraf yang berperan dalam tingkah laku manusia (Wignjcsocbroto., 1995). Aspek kenyamanan adalah kriteria subyektif yang menjadi hal yang penting untuk ditambahkan pada saat ini dan diaplikasikan ke dalam sistem untuk mendapatkan kondisi lebih baik dan mudah. Sebab kondisi ketidaknyamanan pada manusia dapat menyebabkan kesalahan dan ketidakefektifan (Osborne, 1987) .

Ergonomik / kenyamanan kerja mempunyai pengaruh yang nyata dalam hal peningkatan maupun penurunan efisiensi dan efektivitas kerja. Tujuannya adalah untuk memproduksi sistem yang ramah pemakai yakni aman, nyaman, dan mudah digunakan. Ilmu ergonomik disebut juga rekayasa faktorfaktor manusia. Dengan kata lain ergonomik dalam interaksi manusia dan komputer ini menitik beratkan pada karakteristik fisik mesin dan sistem, dan bagaimana hal tersebut mempengaruhi kinerja user. Human factor (faktor manusia) meliputi studi tentang manusia dan tingkah lakunya dalam menggunakan mesin, alat-alat teknologi dan sistem dalam menyelesaikan tugas. Kedua bidang ini memperhatikan kinerja user dalam konteks semua jenis sistem, apakah itu komputer,mekanik, atau manual.

2.5 Aspek Usability

Aspek usability atau daya guna merupakan kajian penelitian Interaksi Manusia dan Komputer (IMK) yang mengacu pada sudut pandang pengguna saat menggunakan dan memanfaatkan suatu produk. Definisi usability menurut International Organization for Standardization atau disingkat ISO 9241-11 
adalah "tingkat di mana sebuah produk digunakan oleh pengguna tertentu untuk mencapai tujuan tertentu dengan efektif, efisien, dan memperoleh kepuasan dalam lingkup penggunaannya"(ISO/IEC, 1998).

Evaluasi usability merupakan kegiatan yang penting dalam pengembangan system interaktif. Rancangan antarmuka pengguna harus melalui iterasidesain dan evaluasi sampai menunjukkan hasil yang memuaskan (Zhang, 2007), dan mudah untuk dipelajari (Nielsen, J, 1993). Evaluasi yang paling relevan untuk sebuah system yakni dengan mengindetifikasi faktor usability (Oztekin, A., Delen D., A. Turkyilmaz and Selim Zaim, 2013). Evaluasi usability sebagian besar ditunjukkan oleh interaksi manusia dan komputer (Moha, 2007).

Secara spesifik tujuan usability sebagai berikut. (Preece, 2002)

1) Efektif untuk digunakan (efektivitas)

2) Efisien untuk digunakan (efisiensi)

3) Aman digunakan (safety)

4) Memiliki utilitas yang baik (utility)

5) Mudah dipelajari (learnability)

6) Cara penggunaan mudah diingat (memorability)

7) Mudah diakses (Accessibility)

8) Pencegahan kesalahan (Error Prevention)

9) Jarak pandang (Visibility)

Dalam proses pengembangan suatu aplikasi interaktif, usability test dan teknik usercentered design telah diakui sebagai faktor yang penting dan perlu diperhatikan pelaksanaannya. Namun pada kenyataannya, faktor tersebut belum tercermin dalam banyak proyek pengembangan aplikasi perangkat lunak (Seffah, 2005).

\subsection{Tentang Aplikasi Ruangguru}

PT. Ruang Raya Indonesia yang dikenal dengan Ruangguru.com merupakan salah satu marketplace bidang pendidikan di Indonesia. Perusahaan penyedia layanan dan konten pendidikan berbasis teknologi yang didirikan pada April 2014 oleh Muhammad Iman Usman dan Adamas Belva Devera.

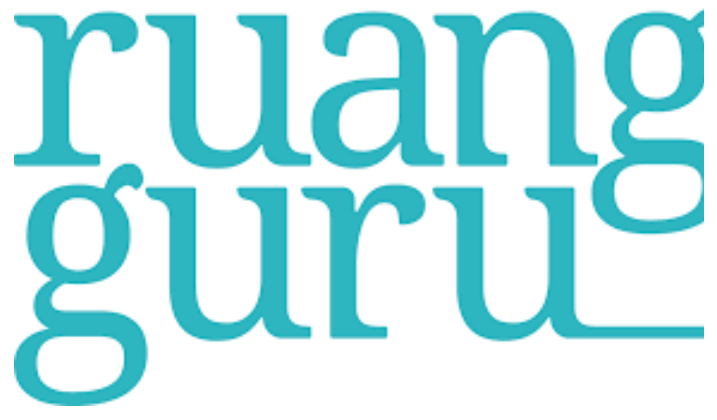

Gambar 1.0 Logo Ruangguru
Latar belakang didirikannya situs

Ruangguru.com adalah ketika pendiri yaitu Muhammad Usman dan Adamas Devera berkesempatan melanjutkan pendidikan ke USA. Pendiri mencoba mencari tahu guru privat online yang sesuai dengan kebutuhan mereka dan menyadari bahwa pasar akan kebutuhan tersebut tidak efisien, sehingga lahir ide untuk membangun marketplace belajar online yang akan menjembatani pencarian antara pelajar dan pengajar yang prosesnya dikemas secara transparan (rating, revies, cost).

Ruangguru.com merupakan sebuah wadah yang menghubungkan pelajar dengan pengajar. Dimana pelajar dapat mencari dan menemukan pengajar berdasarkan kebutuhannya begitu juga sebaliknya, pengajar dapat menyalurkan ilmu yang dimilikinya. Kegiatan belajar-mengajar yang difasilitasi oleh Ruangguru.com menyediakan sistem tata kelola pembelajaran (learning management system) yang dapat digunakan murid dan guru dalam mengelola kegiatan belajar dikelas secara virtual. Dilengkapi dengan ribuan bank soal yang kontennya disesuaikan dengan kurikulum yang berlaku di Indonesia serta peralatan analisis hasil tes dimana pengguna dapat memanfaatkannya tanpa dipungut biaya.

Situs marketplace Ruangguru.com dalam pencarian guru privat telah mengelola lebih dari 4 juta pengguna dan 27.000 guru yang menawarkan jasa di lebih dari 100 bidang pelajaran diseluruh Indonesia sejak didirikan tahun 2014. Ruangguru.com juga sudah dipercaya 326 Pemerintah Kota dan Kabupaten dan 32 Pemerintah Provinsi di Indonesia.

Adapun layanan yang disediakan oleh Ruangguru.com adalah sebagai berikut: 


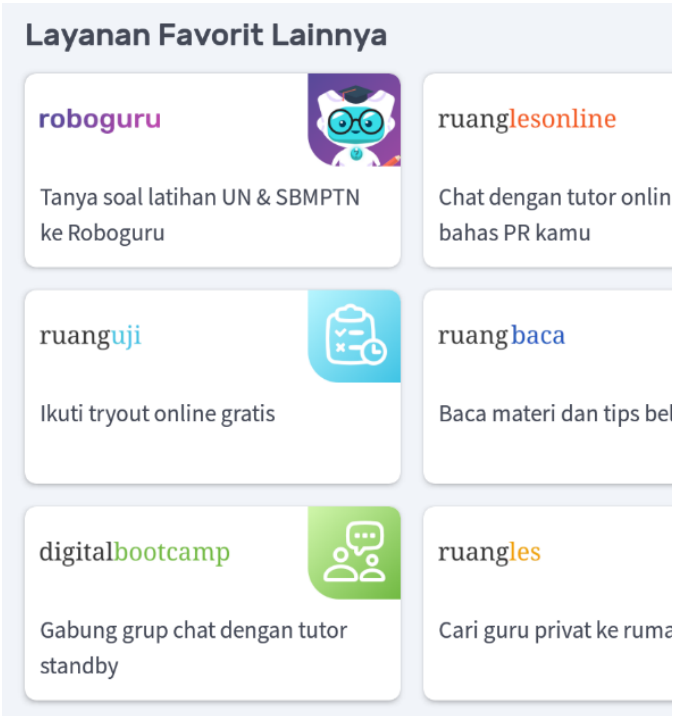

Gambar 2.0 Fitur Ruangguru

1) Ruang Video

Layanan yang menyediakan 1528 video belajar pembahasan materi dan soal latihan dengan durasi kurang dari 10 menit dan dapat di akses melalui aplikasi ruangguru, baik untuk pengguna android maupun ios. Ruang Video dikembangkan berdasarkan silabus kurikulum dari Kementrian Pendidikan dan Kebudayaan yang dikategorikan sesuai dengan topik dan mata pelajaran yang diajarkan. Rangkuman dari konten video yang ditonton dapat diunduh dalam bentuk flashcard untuk digunakan kembali saat belajar mandiri.

\section{2) Ruang Les}

Layanan yang memfasilitasi siswa untuk memesan guru privat mata pelajaran apapun, kapanpun dan dimanapun. Biaya yang harus dibayarkan bervariasi sesuai kebutuhan, setiap pelajar akan dibimbing oleh satu pengajar (1 murid : 1 guru) dan proses belajar mengajar dapat ditentukan oleh pelajar dan modul belajar didapatkan secara online dan cetak.

\section{3) Ruang Les Online}

Layanan yang menyediakan guru online selama 16 jam. Sehingga pelajar yang kesulitan dalam mengerjakan soal disuatu waktu dapat menggunakan fitur Ruang Les Online hanya dengan chat baik dengan teks, audio, dan video. 4) Ruang Latihan

Layanan yang menyediakan soal untuk para siswa di berbagai jenjang sekolah dan kelas. Semua siswa SD, SMP, SMA bisa mengerjakan soal di Ruang Latihan. Mata pelajaran yang tersedia untuk SD adalah Matematika, Bahasa Indonesia, dan IPA. Sedangkan mata pelajaran yang tersedia untuk SMA adalah Matematika, Bahasa Indonesia, Bahasa Inggris, dan IPA Terpadu dan mata pelajaran yang tersedia untuk SMA adalah Matematika, Bahasa Indonesia, Bahasa Inggris, Kimia, Fisika, Biologi, Geografi, Ekonomi dan Sosiologi.

5) Digitalbootcamp

Layanan yang menyediakan ruang bimbel online dalam bentuk grup chat belajar yang tersedia bagi kelas 6 SD hingga kelas 12 (termasuk persiapan SBMPTN), setiap grup chat dibimbing oleh tutor (per mata pelajaran) dan konsultan pendidikan. Pelajar dapat menanyakan pelajaran apa saja sepuasnya selama 24 jam.

Ruangguru.com juga memiliki mobile-app untuk memudahkan pelajar dalam mengerjakan tugas untuk dapat berkomunikasi secara langsung dengan guru online yang standby setiap hari selama 16 jam setiap harinya. Dengan memotret soal yang sulit, upload dan chat/call dengan pengajar online melalui fasilitas yang telah disediakan. Dengan meluncurkan aplikasi mobile on demand pembelajaran jarak jauh menjadi intensif untuk para pelajar dan difasilitasi dengan guru membuat para pelajar dapat memanfaatkan penggunaan smartphone. Sehingga belajar privat kini dapat dilakukan kapan pun dan dimana pun.

Ruangguru.com juga memfasilitasi akses para orang tua dalam memonitor perkembangan belajar anak, melalui aplikasi Ruangguru-Orang Tua yang diluncurkan pada September 2016. Dengan aplikasi Ruangguru-Orang Tua ini orang tua dapat mengetahui jadwal privat, melihat lapor belajar, hingga memberikan rating dan feedback kepada guru untuk mendukung proses pembelajaran yang membuat para murid merasa nyaman.

\section{PEMBAHASAN}

\subsection{Aspek Human Pada Aplikasi}

Ruangguru

Pada aplikasi ruangguru dilihat dari segi user interface sudah dibuat dengan sangat menarik dan mudah dipahami oleh user. User dapat dengan mudah mengenali fungsi dari fitur yang disediakan dalam aplikasi ruangguru.




Gambar 3.0

Tampilan Awal Ruangguru

Ditinjuau dari segi fitur, aplikasi ruangguru menawarkan fitur yang dipandang user friendly dengan konten yang bervariatif mulai dari materi dalam bentuk teks, video pembelajaran bahkan animasi pembelajaran yang dikemas dengan menarik, membuat user (human) lebih mudah memahami materi.

\subsection{Aspek Technology Pada Aplikasi} Ruangguru

Beberapa aspek teknologi yang dapat diamati pada aplikasi Ruangguru diantaranya:

\section{a) Input}

Dalam hal input pada aplikasi Ruangguru ini menyesuaikan dengan perangkat terpasangnya aplikasi seperti keyboard dan navigasi. Pointing dan text input device juga memungkinkan system melakukan copy/paste pada aplikasi Ruangguru. Ketika akan melakukan proses input, keyboard yang dimunculkan (touchscreen) sesuai dengan tugas yang dikerjakan (alphabet atau angka).
b)
Register
Sensori
(Menerima

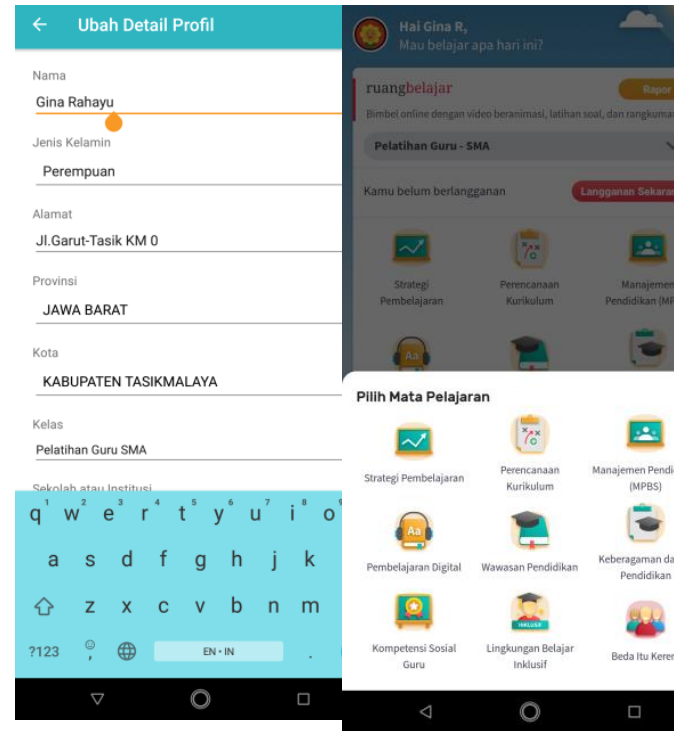

Gambar 4.0 Register Sensori

Terjadi rangsangan untuk menampilkan keyboard ketika kursor/pointer diarahkan pada kolom input seperti dicontohkan pada gambar diatas. Begitu pula rangsangan ketika terdapat konten pilihan pada menu, akan langsung muncul pilihan yang tersedia/ditawarkan.

\section{c) Storage}

Teknologi penyimpanan yang digunakan dalam aplikasi Ruangguru adalah penyimpanan secara online dalam aplikasi, baik itu materi (text/video,dsb) disimpan secara online.

$$
\leftarrow \text { File Manager bos }
$$$$
\triangleleft \quad 0
$$$$
\text { Gambar 5.0 File Manager Aplikasi }
$$$$
\text { Ruangguru }
$$$$
\text { User dapat melakukan }
$$$$
\text { menyimpanan/pengarsipan materi pada fitur File }
$$$$
\text { Manager. Ditinjau dari ukuran aplikasi, }
$$ 
Ruangguru juga memiliki kapasitas/ukuran aplikasi yang terbilang kecil sehingga aplikasi ini dapat dipasang/digunkan dalam berbagai jenis smarthphone yang di dukung.

\section{d) Output}

Terdapat beberapa jenis konten yang disajikan diantaranya pemaparan materi dalam bentuk teks dan video juga tersedia latihan soal pada setiap sesi hya. Hasil output dari aplikasi Ruangguru baik berupa teks atau video ditampilkan pada layar yang sama (tidak melalui frame/tab terpisah). Kemudian di setiap akhir konten/pembelajaran, user diberikan output berupa report/laporan pencapaian pembelajaran. Melalui laporan tersebut user dapat mengetahui sejauh mana pencapaian dan keberhasilannya pada setiap konten materi yang dipelajari.

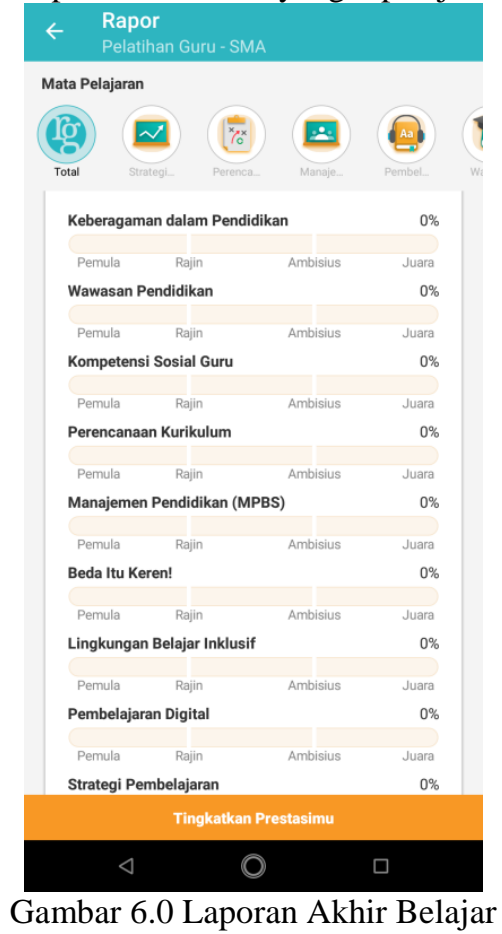

3.3 Aspek Usabillity Pada Aplikasi Ruangguru

Berdasarkan aspek ussabillity, sebuah aplikasi diharapkan dapat menyajikan kemudahan bagi pengguna/user. Dalam mengkaji aspek ini kami menggunakan tahapan "Evaluasi Heuristik" sebagai pendekatan dalam melakukan evaluasi terhadap suatu sistem manusia-mesin (manmachin system) kaitannya dengan kemudahan penggunaan (usability). Evaluasi heuristik berkaitan dengan kecocokan antara sistem dan dunia nyata, konsisten dan standar, pencegahan kesalahan, fleksibilitas dan efisiensi, kaitan dengan keindahan dan desain yang minimalis, bantuan terhadap user apabila terjadi kesalahan dan cara memperbaiki serta bantuan dan dokumentasi.

\section{a) Visibility of System Status}

Sebuah sistem seharusnya dapat memberikan informasi kepada pengguna terhadap apa yang sedang terjadi. Seperti ditunjukkan pada gambar berikut.

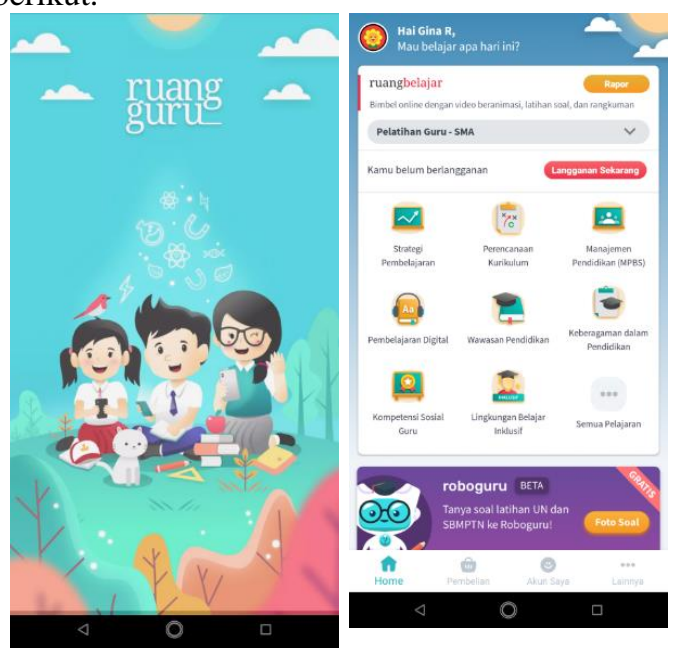

Gambar 7.0 Visibility of System Status

Sebelum pengguna masuk pada home screen App Mobile Ruangguru ini akan tampil background screen sebagai tampilan awal . Pada background screen ini pengguna sudah dapat mengidentifikasi bahwa tampilan ini adalah bagian dari loading sistem App Mobile Ruangguru.

b) User Control and Freedom (Navigation)

Perlu adanya suatu fungsi atau tombol agar pengguna dapat "exit" dari sistem.

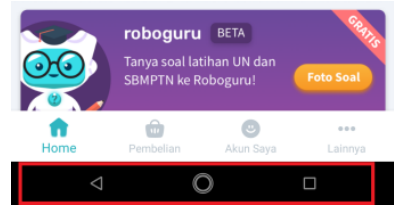

Gambar 8.0 User Control and Freedom (Navigation)

Pengguna secara tidak sengaja sering memilih menu yang tidak di inginkan. Oleh karena itu dibutuhkan tombol "exit". Tapi penulis dan desainer pada pembuatan mobile app Ruangguru ini tidak menerapkan tombol "exit" dikarenakan platform yang dipakai adalah mobile sedangkan pada mobile terdapat tombol "back/undo" sehingga tidah perlu dirisaukan jika pengguna salah melakukan pilihan pengguna tinggal tekan tombol back maka akan cancel jika terjadi kesalahan dalam penggunaannya. 
c) Consistency and Standard (consistency)

Hindari penulisan kalimat, huruf dan situasi lainnya yang berbeda sehingga menimmbulkan kesan tidak standar dalam suatu sistem.

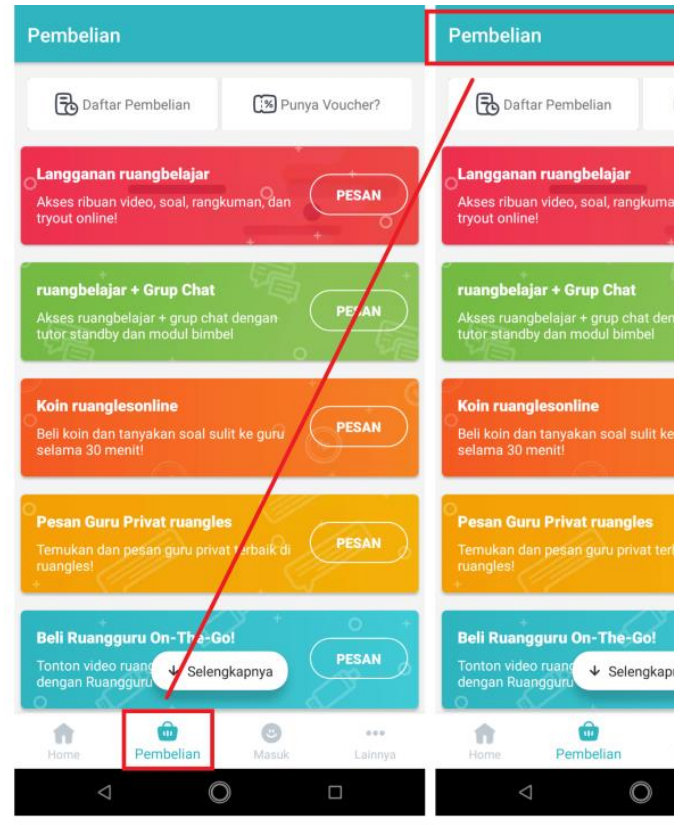

Gambar 9.0 Consistency and Standard (consistency)

Sistem seharusnya tidak membuat bingung pengguna perihal kata, situasi dan perilaku yang berbeda dapat berarti hal yang sama. Aplikasi Ruangguru ini memiliki konsistensi yang baik, setiap halaman memiliki desain, warna dan tema yang sama. Header dan menubar juga selalu berada di lokasi yang sama. Hal ini berkaitan dengan standart situs mobile yaitu sederhana, tema yang minimalis dan tidak menggunakan tampilan grafis yang rumit.
d) Error Prevention

Desain yang dapat mencegah pengguna untuk melakukan kesalahan merupakan hal yang penting dalam suatu sistem.

Aplikasi Ruangguru menggunakan button pada pemilihan proses,kesalahan pada input dapat diminimalkan.

e) Aesthetic and Minimalist Design Perlu diperhatikan empat prinsip dalam desain tampilan/visual yaitu kontras, repetition/pengulangan, alignment dan cahaya.

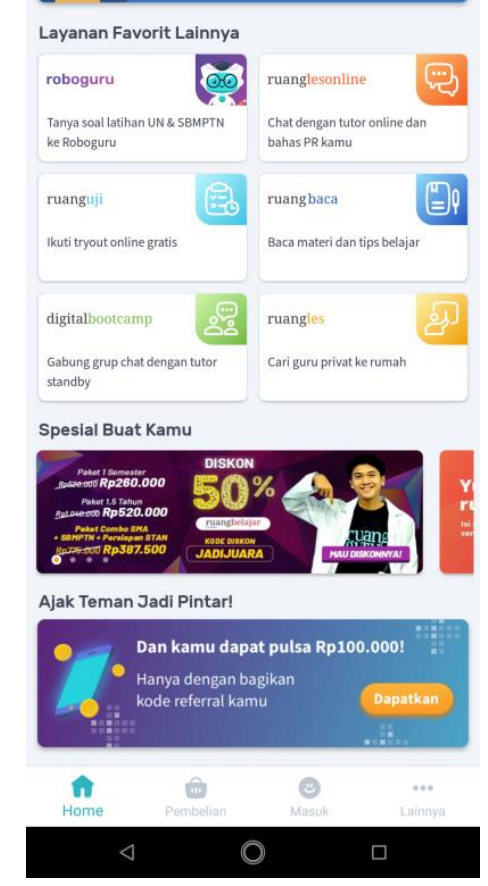


Gambar 11.0 Aesthetic and Minimalist Design

Sebuah dialog tidak boleh mengandung konten atau informasi yang tidak relevan dan tidak diperlukan. Setiap komponen harus mengandung arti dan fungsi yang sesuai dengan keperluan. Aplikasi Ruangguru diperuntukkan bagi perangkat mobile, sehingga desain yang ditampilkan pun sederhana dan minimalis.

f) Help User Recognize, Diagnose and

\section{Form Error}

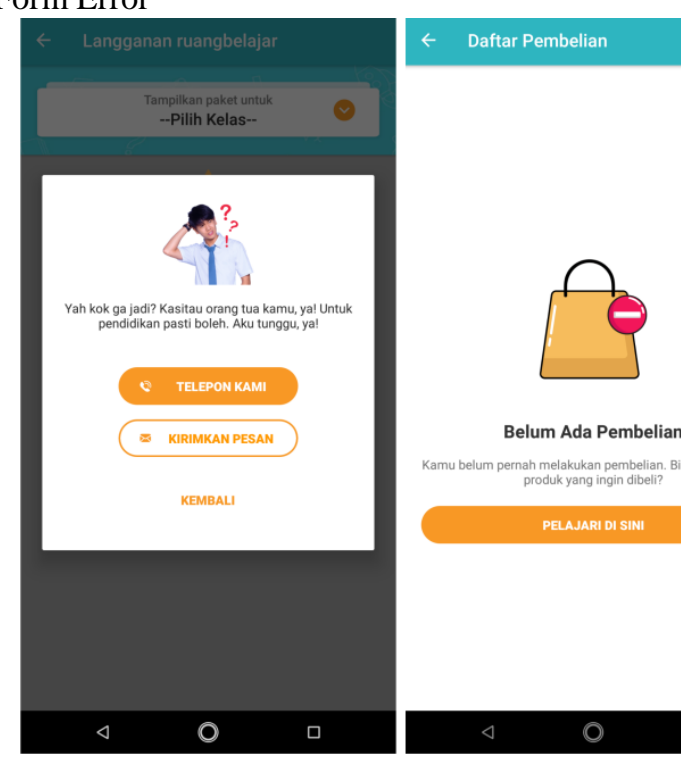

Gambar 12.0 Help User Recognize,

Diagnose and Form Error

Pesan kesalahan yang ditampilkan pada aplikasi Ruangguru ditampilkan berupa bahasa pengguna (bukan berupa kode), secara langsung mengidentifikasikan masalah dan memberikan solusi.

3.4 Aspek Ergonomic Pada Aplikasi Ruangguru

Beberapa aspek ergonomic GUI yang dapat di amati pada aplikasi Ruangguru diantaranya:

a) Consistency / Konsisten : penggunaan ikon, font, dan warna pada setiap screen aplikasi selalu konsisten dan bersesuaian.

b) Simplicity / Kesederhanaan : desain aplikasi menggunakan ikon yang familiar dikalangan user yang mempermudah pengoperasian/implementasi aplikasi.

c) Human memory limitations / Keterbatasan Memori Manusia : system aplikasi tering kali membatasi jumlah informasi untuk meminimalkan beban memori dengan menyediakan perigatan jika terdapat kesalahan pengoperasian user. (Misal : peringatan jika salah memasukan password ketika akan login user). d) Cognitive directness / Kejelasan Kognitif : penggunaan ikon yang sesuai dengan konten atau peringatan yang diberikan.

e) Feedback / Umpan Balik : muncul umpan balik yang diberikan oleh system kepada user dalam setiap aksi (Misal : animasi loading ketika system sedang melakukan proses yang membutuhkan waktu seperti saat login).

f) System messages /Pesan Sistem : pesan kesalahan yang diberikan oleh system mudah dipahami dengan menggunakan kalimat dengan kata baku.

g) Attention / Perhatian : perhatian yang diberikan aplikasi Ruangguru sesuai dengan maksud dan tujuannya, perhatian pada background dan warna dibuat dengan konsisten.

h) Display issues / Masalah tampilan : penempatan fungsi ikon mudah dipahami dan berkesesuaian serta penggunaan kata yang jelas/tidak ambigu.

\section{KeSIMPULAN}

Aplikasi Ruangguru memiliki user interfaces yang user friendly dan mudah dipahami oleh user. Kesesuaian ikon, warna, tata letak fitur, dan petunjuk membuat user tidak perlu menggunakan buku panduan atau kebingunan mencari petunjuk aplikasi, user hanya perlu meniru perilaku yang sesuai dengan pengetahuan yang dipahami.

Dari aspek teknologi, Ruangguru telah memiliki teknologi yang dinilai sudah sesuai dengan kebutuhan user serta memenuhi syarat interaksi manusia dengan komputer. Pengembang sudah dapat memahami karakteristik user sehingga fasilitas yang disediakan bersesuaian dengan kebutuhan user. Register sensori yang ditimbulkan oleh sistem aplikasi sudah bersesuaian, sistem mengetahui perintah yang diminta dan menjalankan sesuai perintah user.

Berdasarkan evaluasi heuristik yang dilakukan terdapat kesesuaian/kecocokan antara sistem dan dunia nyata, konsisten dan standar, pencegahan kesalahan, fleksibilitas dan efisiensi, kaitan dengan keindahan dan desain yang minimalis, bantuan terhadap user apabila terjadi kesalahan dan cara memperbaiki serta bantuan dan dokumentasi. Beberapa aspek yang di evaluasi pada aplikasi Ruangguru ini diantaranya Visibility of System Status, User Control and Freedom (Navigation), Consistency and Standard (consistency), Error Prevention, Aesthetic and Minimalist Design, dan Help User 
Recognize, diagnose and form error (recovery). Merujuk hasil evaluasi tersebut aplikasi Ruangguru telah memenuhi kesesuaian aspek usabillity interaksi manusia dan komputer.

Ditinjau dari aspek ergonomic aplikasi Ruangguru bisa memenuhi aspek kenyamanan GUI berdasarkan sajian dari fitur yang tersedia aplikasi. Kesesuain antara sistem dan GUI yang ditampilkan membuat user nyaman dengan ruang belajar sistem. Penempatan ikon, pesan kesalahan dan feedback pun mudah dipahami sehingga user tidak mungkin kebingungan. Selain itu display yang disajikan juga telah mempertimbangkan aspek pada interaksi manusia dan komputer.

Berdasarkan hasil kajian melalui beberapa aspek, yaitu aspek human, teknologi, usability, dan ergonomic. Aplikasi rungguru banyak diminati oleh user atau pengguna khususnya pelajar karena aplikasi ini memberikan kemudahan belajar dengan menyenangkan dan menarik dengan sajian yang tidak hanya berupa teks tetapi terdapat konten dalam bentuk lain seperti video, animasi, dan latihan soal pada setiap topiknya. Kemudian di akhir pembelajaran disuguhkan laporan hasil belajar dengan teknologi yang menarik dimana user dapat mengetahui sejauh mana kemampuannya pada setiap topic yang dikerjakan. Selain itu, fungsionalitasnya pun tidak diragukan lagi, karena Ruangguru merupakan platform belajar online yang menyediakan guru private yang sudah berpengalaman yang dapat dengan mudah ditemukan melalui layanan belajarnya.

\section{Daftar Pustaka}

[1] Alan Dix, J. F. (2004). Human-Computer Interaction_Third Edition. Pearson Prentice Hall.

[2] Alan Dix, Janet Finlay, Gregory D.Abowd, Russell Beale. (2004). Human-Computer Interaction. England: Pearson Prentice Hall.

[3] Armalina, V. (2011). InteraksiManusia Dan Komputer (HumanComputer Interaction).

[4] Insap Santoso. (2004). Interaksi Manusia dan Komputer Edisi 2. Yogyakarta: Andi.

[5] Moha, N. G. (2007). Remote.Usability valuation of Web Interfaces, HumanComputer Interaction Research In Web Design an Evaluation. Idea Group Inc.

[6] Nielsen, J. (1993). Usability Engginering. San Francisco: ISBN 0-12-518406-9.
[7] Nurmianto, E. (1996). Ergonomi: Konsep Dasar dan Aplikasinya. Surabaya: Guna Widya.

[8] Osborne, D. (1987). Ergonomics at Work 2ndEdition. New York, Brisbane, Toronto, Singapore: John Wiley \& Sons, Chichester.

[9] Oztekin, A., Delen D., A. Turkyilmaz and Selim Zaim. (2013). A machine Learning-based Usability Evaluation Method for eLearning Systems, Decision Support Systems.

[10] Pratiwi, D. A. (n.d.). Mengenal Interaksi Manusia dan Komputer.

[11] Preece, J. R. (2002). Interaction design: beyond human-computer interaction. John Wiley \& Sons, Inc.

[12] Prihati. (n.d.). Penerapan Model Human Computer Interaction (HCI Dalam Analisis Sistem Informasi)" Studi Kasus SAS Dikmenti DKI Jakarta.

[13] Rahadian, Dian. "Peran dan Kedudukan Guru dalam Masyarakat." JURNAL PETIK 1.1 (2015): 26-37.

[14] Rahadian, Dian. "PERGESERAN PARADIGMA PEMBELAJARAN PADA PENDIDIKAN TINGGI." JURNAL PETIK 2.1 (2016): 1-7.

[15] Sastry, H. (2011). User interface design challenges for digital libraries. International Journal of Computer Applications, 7-11.

[16] Seffah, G. D. (2005). Human-Centered Software Engineering - Integrating Usability in the Software Development Lifecycle. Springer Science \& Business Media.

[17] Wignjcsocbroto., S. (1995). Ergonomi : Studi Gerak dan Waktu, Teknik Analisis Untuk Peningkatan Produktivitas Kerja. Jakarta: PT. Guna Widya.

[18] Zhang. (2007). Usability Evaluation. Human-Computer Interaction Research In Web Design an Evaluation (pp. 209228). Idea Group Inc 